\title{
頸部脊椎症とへルニアの外科治㙩
}

$$
\begin{array}{lllllll}
\text { 岩 } & \text { 崎 } & \text { 喜 } & \text { 信 } & \text { 飛 } & \text { 騨 } & \text { 一 } \\
\text { 小 利 } \\
\text { 小 柳 } & & \text { 泉 } & \text { 阿 } & \text { 部 } & & \text { 弘 }
\end{array}
$$

\section{Surgical Methods for Treating Diseases of the Cervical Disc}

by

Yoshinobu Iwasaki, M.D., Kazutoshi Hida, M.D., Izumi Koyanagi, M.D., and Hiroshi Abe, M.D.

$$
\text { from }
$$

Department of Neurosurgery, Hokkaido University School of Medicine

The emphasis of this report is the surgical technique for a disease of the cervical disc. In addition to the Smith -Robinson method, there are many other operative methods that can be considered, such as the Cloward method, a corpectomy or without a bone graft using an anterior approach, and a laminectomy or an expansive laminoplasty for posterior decompression. However, it appears that is generally agreed that an anterior approach is more effective than posterior decompression.

At our institute, our first choice is usually the Smith-Robinson method under microscopy. When using this method, great attention should be taken, not only to avoid a cord injury but also to prevent postoperative hoarseness due to an injury that may occur to the recurrent laryngeal nerve and/or a sensory disturbance of the thigh due to a lateral femoral cutaneous nerve injury. Therefore, the surgeon performing this operation must be well acquainted with the anatomical structure concerned. As for cases manifesting multilevel regions and a severely narrowed spinal canal, posterior decompression is the method selected, and we have recently been using an expansive laminoplasty as the surgical approach. This is because an expansive laminoplasty, unlike a laminectomy, has additional merits, such as postoperative stabilization of the cervical spine and protection against an over-tethering injury of the nerve roots.

(Received \& accepted October 13, 1994)

Key words : cervical spondylosis, cervical soft disc, anterior approach, expansive laminoplasty Jpn J Neurosurg (Tokyo) $4: 17-22,1995$

\section{はじめに}

一般に頸椎椎間板障害は若年〜中年に多い soft disc hernia（椎間板へルニア），および中〜高年齢に多い spondylosis（頸部脊椎症）を示す。頸椎椎間板障害は腰 椎のそれとともに脊髄疾患の中でも最も高頻度にみられ る疾患である．特に近年の MRI の普及により外科的に 容易に診断がつくようになってきたため, 脳神経外科施 設における経験症例も年々増加してきているのが現状で
ある、しかしながら，ここで注意すべきことは，ほかの 重篤な頭蓋内疾患と異なり, 頸椎椎間板障害は致命的な 疾患ではなく，その外科的治療もむしろ機能外科のカテ ゴリーに属するものであることである，すなわち，その 手術時期のタイミング，障害椎間板レベルの同定はもと より，手術手技においても少なくとも術前よりも症状の 悪化をきたさ奴うに病態像を十分把握したうえで細心 の注意を払う必要がある．以上のことから本稿において は，われわれが現在行っている手術手技を中心に，手術

北海道大学医学部脳神経外科 [連絡先：岩崎喜信, $\overline{\mathrm{T}} 060$ 札幌市北区北 14 条西 15 丁目]

Address reprint requests to : Yoshinobu Iwasaki, M.D., Department of Neurosurgery, Hokkaido University School of Medicine, Nishi 15 chome, Kita 14 jyo, Kita-ku, Sapporo-shi 060, Hokkaido, Japan 
時期, 手術術式の選択等についても報告する.

\section{症状発現の機序ならびに治療法の選択}

当然のことであるが，神経症状の発現は突出椎間板あ るいは骨棘が脊䯣や神経根を圧迫することによって起こ る. soft disc の場合，通常は単一椎間板腔に起こること が多いが，突出椎間板の方向により異なった神経症状を 呈する。すなわち脊柱前面正中部に突出する場合（central type) は主にミエロパシーを，傍正中部の場合 (paramedian type) はラディクロミエロパシーを，外側 部の場合 (lateral type) はラディクロパシーを引き起こ すことが多い。一方 spondylosisに扔いては，責任病巣 を含めて，多椎間板脭饮頸椎症様の変化がみられること が多い，骨棘や変性椎間板の突出方向により症状が変化 する可能性があることは soft disc と同様であるが，一 般には骨棘抢よび変性椎間板の突出は diffuse のことが 多いため，症状もラディクロミエロパシーを呈すること が多い．また，通常椎間板の突出は頸椎の伸展位で増強 し，この際黄色鞄帯の脊柱管内への突出もみられること があり，このため脊能道は前方および後方から挾みつけら れるように圧迫される場合がある。このほか，頸椎症で は伸展位で隣接椎体間のずれ (subluxation) が生じやす く，これにより圧迫がさらに増強することも多い。

治療法は大きく分けて保存的治療と外科的治療があ る. 保存的治療としては, 頸部カラー, 安静, 頸部牽引, 薬剂投与などがあげられるが，頸部牽引は長軸方向に頸 椎あるいは頸能博が引張られることにより，新たな脊䯣 の損傷が起こって症状の増悪をみることが稀ならずある ので注意を要する。

外科的治療はさらに直接除压を目的とする前方到達法 と間接的除圧法である後方除圧術に分けられるて). 前方 到達法には代表的な Smith-Robinson 法 ${ }^{12)}$ をじめと $し て$, Cloward 法 ${ }^{1)}$, 椎体削除法 ${ }^{4)}$, without bone graft 法11などさまざまな方法がある。一方後方除圧法には古 典的な椎弓切除法のほかに，最近多くの施設で行われる ようになってきた脊柱管拡大術がある。

なお脊柱管拡大術は多くの手術術式が考案されてお り229)101), 統一的な術式は末だ確立されていない. 手術の 時期としてはまず，頸部カラーなどによる保存的治療を 行って約 1 力月位経過をみたうえで，手術適応の有無を 十分検討して行うことが一般的である。また，この経過 観察中に患者側に病態および手術内容の説明を十分行う べきである。

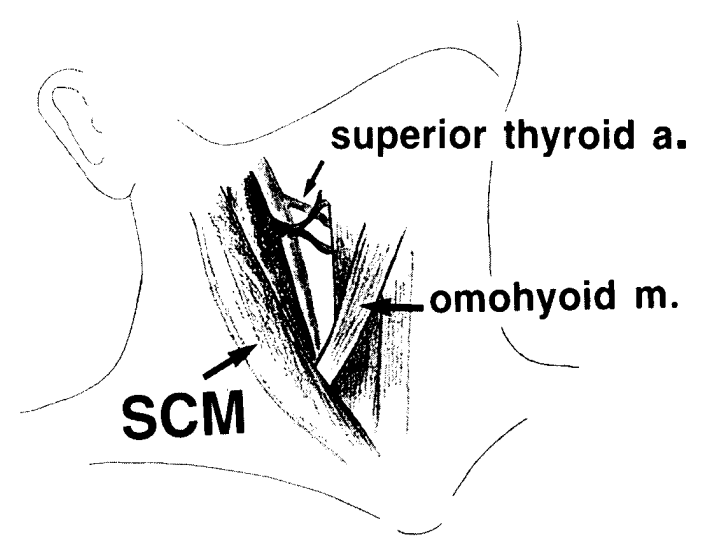

Fig. 1 The cervical anatomy

The major vessels are situated under the sternocleid mastoid muscle (SCM). The approach to the targeted vertebrae should be along the lateral margin of the infrathyroid muscles.

\section{手術手技}

先に述べたごとく，外科的治療として多くの手術方法 があるが，ここではわれわれが行っている前方到達法 (Smith-Robinson 法) と，脊柱管拡大術（観音開き法) についてその手技の概略を示す。

\section{1 前方到達法}

通常右側より椎体前面に到達する。すなわち右側頸部 の胸鎖乳突筋前縁やや正中寄りの斜切開にて皮膚および 広頸筋を切開する。この際，皮下組織と広頸筋をできる かぎり豩離せずに，同時に切開を加えた方が術後の皮䖉 切開部の治癒が早く搬痕も少ない.

次いで頸筋群を剥離していくが，この際，教科書では 通常胸鎖乳突筋の前緑に沿って侵入していくと記されて いるが，実際には正中部近くに存在する甲状筋群（甲状 舌骨筋, 胸骨甲状筋）の外側縁に沿って侵入した方が安 全である。もし胸鎖乳突筋前縁に沿って剥離を進めてい

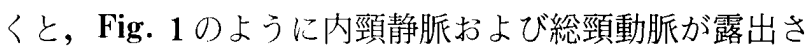
れることになり，それらの大血管に不用意な操作が加わ る危険性がある。さらに $66 / 7$ レベル以上の頭側の椎間 板操作が目的の場合は，肩甲舌骨筋よりも頭側で各筋群 の豩離を進める。この理由は反回神経が下甲状腺動脈付 近で正中方向へ走向し，その後気管と食道間のやや外側 を上行するため，肩甲舌骨筋よりも尾側での侵入では， 下甲状腺動脈付近で，この神経を損傷する可能性がある ことによる (Fig. 2). 椎体前面を露出後, 目的とするレ ベルをX線写真にて確認し，椎体両外側の頸長筋を椎体 部より止血しつつ剝離する．次いで開空器にて術野を確 保するが，この際開空器のブレードを椎体と頸長筋間に 


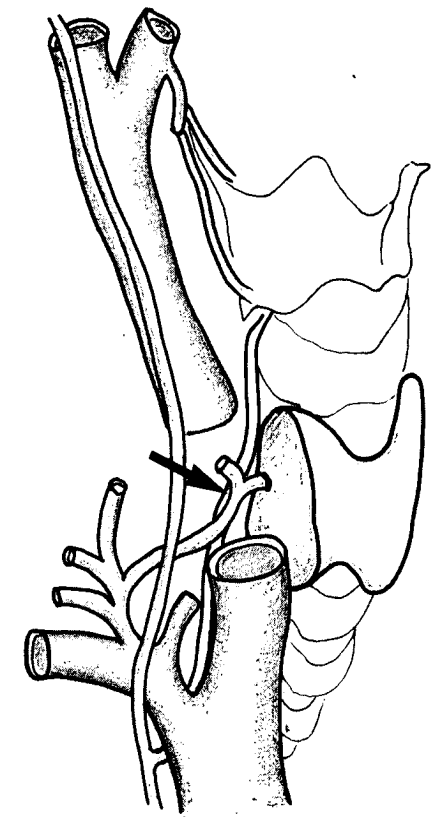

Fig. 2 Anatomy of the recurrent nerve

The recurrent laryngeal nerve runs quite close to the inferior thyroid artery (arrow).
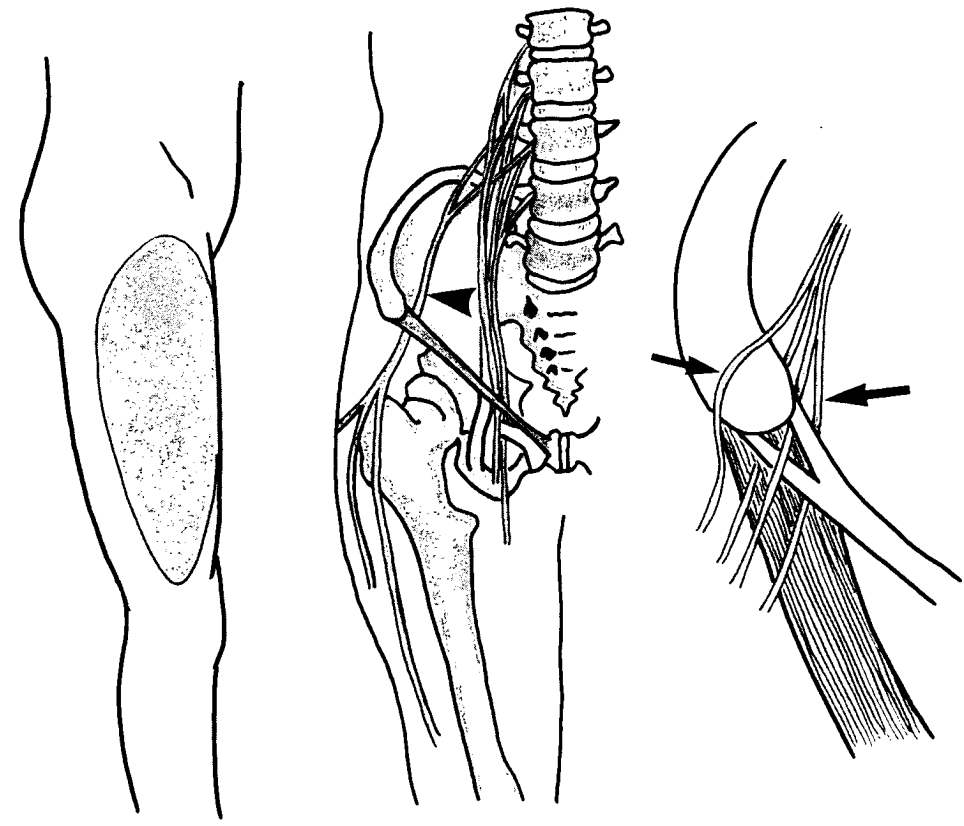

Fig. 3 Anatomy of the lateral femoral cutaneous nerve (arrow head)

There are some variations at the iliac bone in the running of this nerve (arrows).
挿入する。こうすることにより，気管，食道，反回神経， 総頸動脈のブレードによる強い圧迫を防止することがで きる。

椎間板抢よび骨棘の除去は手術顕微鏡下に慎重に行う が, 頸椎スプレッダーにて椎間腔を広げた後, 鋭匙にて 変性椎間板を摘出し，後縦勒带を筥出する，椎間板を除 去することにより，骨棘の突出の程度や広がりが全体像 として確認できる。骨棘の除去はダイアモンドバーによ り骨棘を薄くした後，鋭匙で除去する方が安全である。 骨棘の除去に際しては，外側まで十分に削除し，神経根 の除圧を図ることが大切である。椎間板掞よび骨棘の除 去が終了した後も，もし術前の検查で migrated disc が 疑われた場合は，後䋛勒带を切開して椎間板片の迷入の 有無を確認すべきである。

骨固定の際の移植骨は通常腸骨稜より採取するが，こ の場合注意すべきことは，採取時の操作による外側大朋 皮神経の損傷を起こさぬことである，外側大腿皮神経の 走行はFig. 3 のごとく一般的には前腸骨棘の直下を通る が，稀に前腸骨棘の近くで腸骨稜上を横切るように走る 例もある。したがって神経損傷を起こさ㰠ためには, 前 腸骨棘付近での骨採取を避けるべきである。われわれは このため皮䖉切開は前腸骨棘より後方 $1.0 \mathrm{~cm}$ までとし, さらに腸骨稜の剝離操作も, 前腸骨棘より後方 $2.0 \mathrm{~cm}$ か ら後部で移植骨の採取を行っている。

移植骨は高さ $8 \mathrm{~mm}$ ，奥行き $1.3 \sim 1.5 \mathrm{~cm}$ の大きさの
ものを插入する。術後の頸部固定は頸部カラーにて行う が，われわれは約 1 力月間は硬性力ラー (I. K. A. 力 ラー）とし，その後 $1 \sim 2$ カ月ソフトカラーを装着して いる。なお，C5/6 または C $6 / 7$ の単一椎間の soft disc， あるいは骨棘が軽度な頸椎症に打いては，without bone graft 法を採用する場合もあるが，この場合は病変部の 後緃勒带は切離除去する。また，多椎間病変の場合 with bone graft 法と without bone graft 法を併用するいわ ゆる combined method を採用することもある5).

\section{2 春柱管拡大術}

腹臥位とし，頸部を水平になるように手術台を調整す る。型通りの正中皮䖉切開にて術野を展開し, 根弓招よ び棘突起を露出する。棘突起を切除後, 椎弓の正中部, および両側の椎湴根の内側部に air drillにて縦方向の骨 溍を作製する。この際 facetectomy が必要なレベルがあ る場合は,さらにそのレベルの椎弓根を削除し root の後 方除圧を行う。

次いで, 正中㧍よび両外側の削除をさらに進め, 完全 に椎弓を離断する。この後鋭匙を用いて一気に椎弓を左 右に観音開き様に展開する (Fig. 4)。この時左右の椎弓 は，骨成分の離断はあるが黄色勒带で椎弓根部となおつ ながっている。左右に展開した椎弓は，隣接椎弓間の黄 色勒带と傍脊柱筋とを縫合することにより固定するが， この際, 切離した棘突起を利用して, マッチ棒状に細工. 


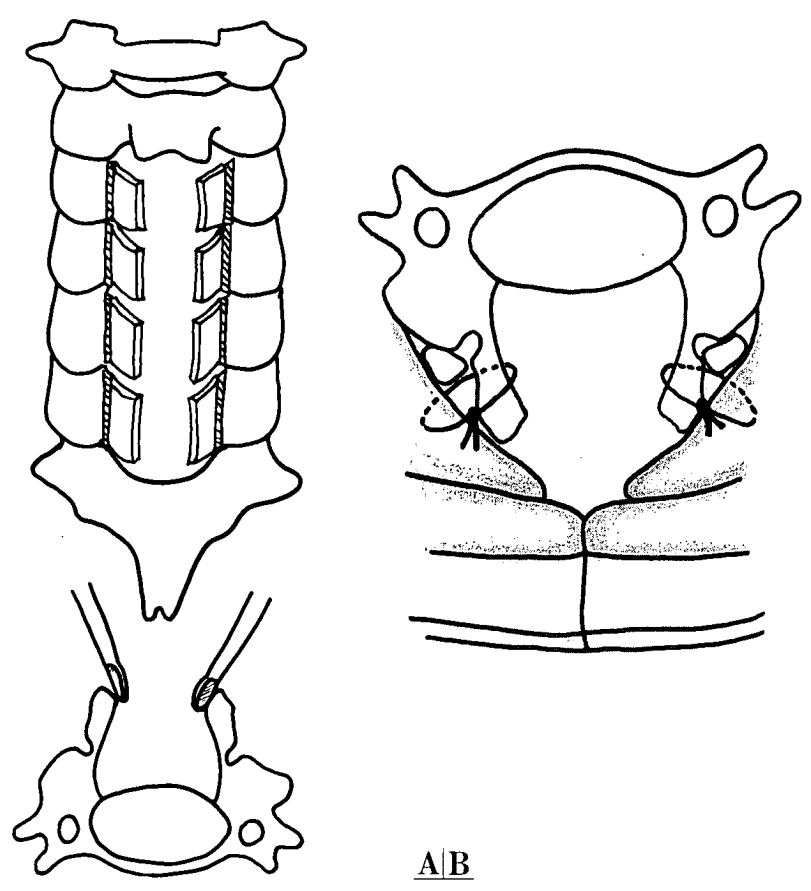

Fig. 4 A schematic drawing of an expansive laminoplasty

A : A groove is made on each side of the lamina, and the lamina is separated at the midportion. Both sides of the lamina are then lifted and opened like a pair of folding doors.

B : The lifted laminas are fixed to the paravertebral muscles with the yellow ligament by means of sutures.

した骨片を椎弓と椎弓根間に挾めるように挿入する．術 後はソフトカラーを約 2 カ月間装着する。

\section{手術成績}

当施設において手術が施行された頸部椎間板症例は過 去 10 年間で 425 例であった。このうち頸椎症は 340 例, soft disc 例は 85 例であった。手術術式の内訳は，前方 到達法においては without bone graft が, 頸椎症 35 例, soft disc 31 例の計 66 例, with bone graft が, 頸椎症 185 例, soft disc 48 例の計 233 例, combined method が 頸椎症 69 例, soft disc 2 例の計 71 例であり, 総計では 370 例に前方到達法が施行された（Fig. 5).

なお，手術施行椎間板数では，単一椎間板障害の割合 は soft disc の方が頸椎症よりも圧倒的に多かったが (soft disc 51/81, 頸椎症 77/289), 2 椎間以上では soft $\operatorname{disc} 30 / 81$, 頸椎症が 212/289 と頸椎症の方が多かった。 一方, 後方除圧法は総計 55 例に施行されたが, 術式の内 訳では以前は laminectomy が大多数であったが，最近 は逆に expansive laminoplasty がほぼすべての症例で 行われるようになった（Fig. 6).
$\underline{\mathbf{A} \mid \mathbf{B}}$

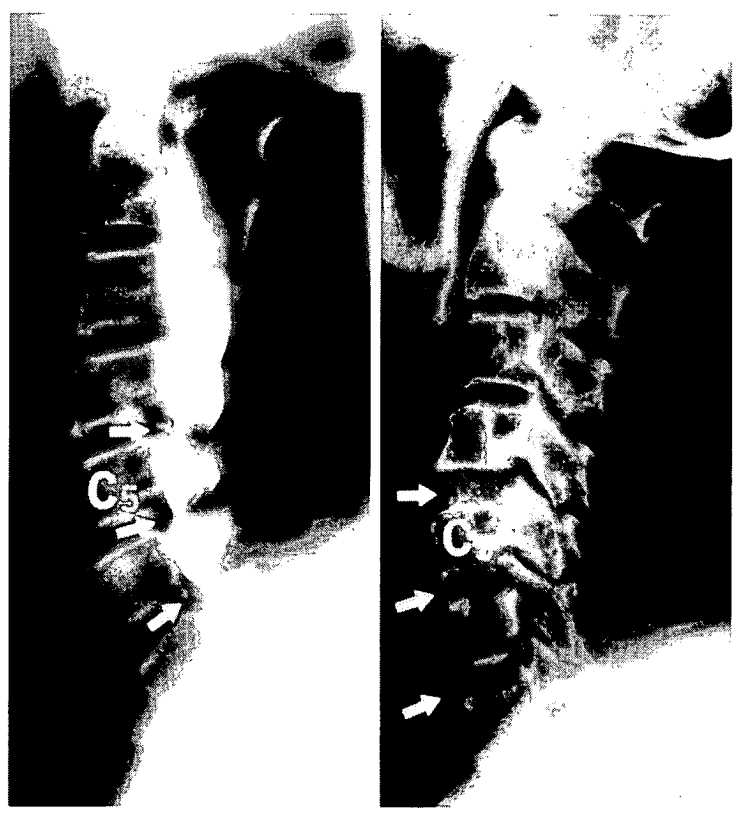

Fig. 5 A case of an anterior approach

A : A preoperative myelogram shows cord compression at the $\mathrm{C} 4 / 5, \mathrm{C} 5 / 6$ and $\mathrm{C} 6 / 7$ levels.

B : A postoperative $X$-ray shows fusion at each of the three levels accomplished with bone grafts.

術後の手術成績は当施設に NCSS (Neurosurgical Cervical Spine Scale) を採用するようになってからの 症例で検討した。その結果は Table 1 に示した通りであ り，全体的にみて前方到達群の方が後方除圧群よりも改 善率は良好である。また，後方除圧群においては laminectomy よりも laminoplasty の方が改善率は優れ ている.

以上のように NCSS は術後成績の評価にとり,優れた 評価法といえる。

\section{考察およびまとめ}

頸部椎間板障害は高䟻化社会が現実のものとなってき たことや，画像上容易に発見されるようになったことな どから，年々その数は増加してきている。一方，機能外 科的な面を有することより，治療の選択には慎重であら ねばならないし，また，手術もより安全でなければなら ない.このため治療する側としては, 病態像の把握が十 分に行い得る知識の習得はむろんのこと，手術に関与す る頸部の解剖および手術手技の習熟は必須のものであ る.こうした意味から手術法および手技の改良も大切で ある。前方到達法に関しては Cloward 法や SmithRobinson 法で, 以前は肉眼での手術操作が行われてい たが，近年は手術顕微鏡下での micro technique を用い ることが通常となっている5)6)8).ただし，移植骨を用い 


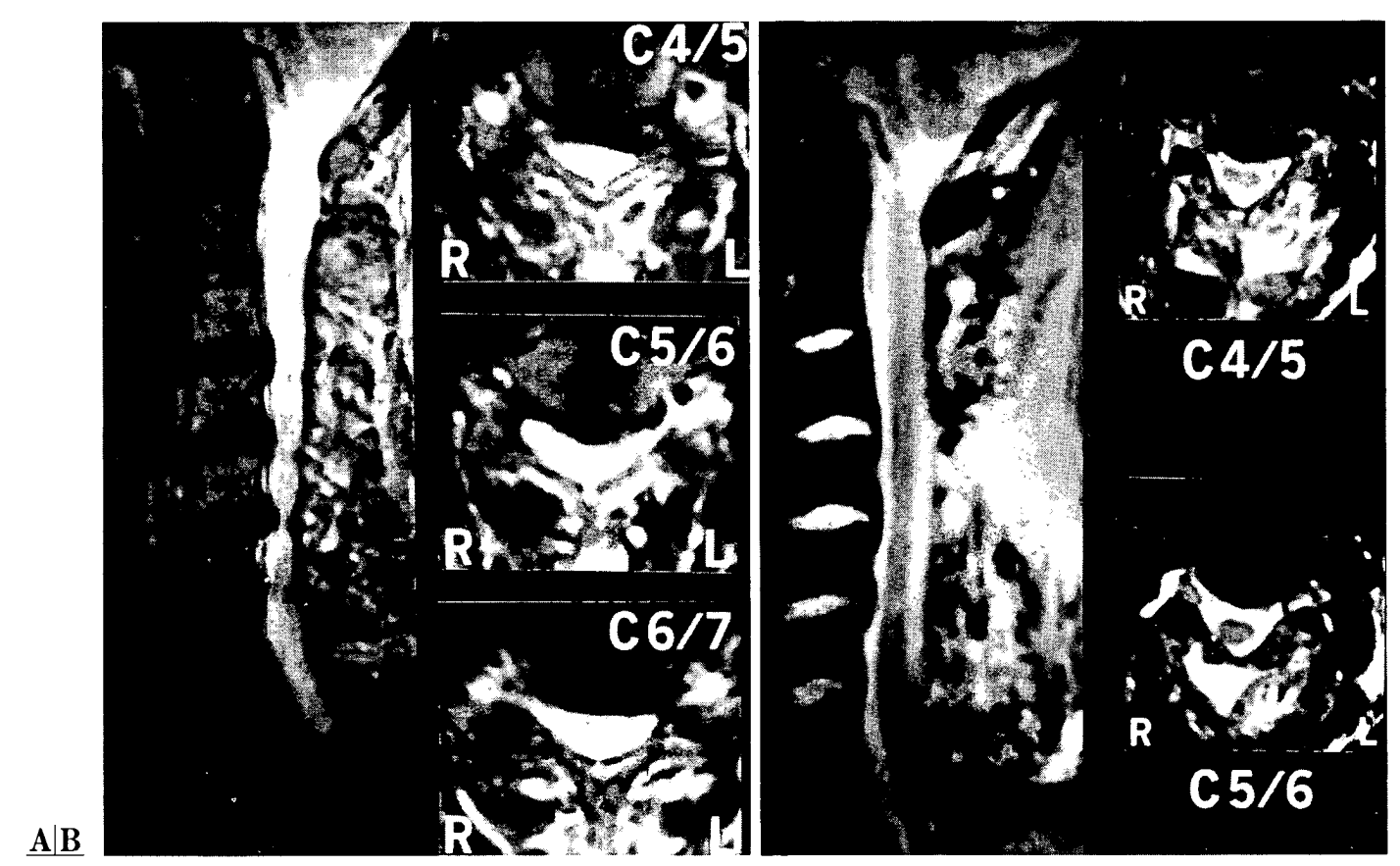

Fig. 6 An expansive laminoplasty case

A : A preoperative MRI shows a severely narrowed canal and cord compression at multiple levels.

B : A postoperative MRI shows decompression of the cervical cord.

Table 1 Operative results

\begin{tabular}{|c|c|c|c|c|c|c|c|c|}
\hline & \multirow{2}{*}{ Type of Surgery } & \multirow{2}{*}{$\begin{array}{r}\text { No. of } \\
\text { Cases }\end{array}$} & \multirow{2}{*}{$\begin{array}{c}\text { Improvement rate } \\
(\%)\end{array}$} & \multicolumn{5}{|c|}{ Performance status } \\
\hline & & & & $\mathrm{V}$ & IV & III & II & I \\
\hline \multirow{4}{*}{ Spondylosis } & anterior approach & 62 & 80 & 51 & 8 & 2 & 1 & 0 \\
\hline & corpectomy & 4 & 71 & 4 & 0 & 0 & 0 & 0 \\
\hline & laminectomy & 5 & 47 & 3 & 0 & 0 & 2 & 0 \\
\hline & expansive laminoplasty & 11 & 74 & 7 & 2 & 2 & 0 & 0 \\
\hline \multirow{2}{*}{ Soft disc } & anterior approach & 4 & 87 & 3 & 1 & 0 & 0 & 0 \\
\hline & laminectomy & 1 & 72 & 0 & 0 & 0 & 1 & 0 \\
\hline
\end{tabular}

An analysis based on the Neurosurgical Cervical Spine Scale (NCSS).

ての前方固定術は, 術後の固定期間が長い, non union の 可能性がある，移植骨採取時の外側大腿皮神経の損傷の 危険性があるなどいくつかの問題がある。このため最近 は病変部の椎体を利用して移植骨とする方法も行われる ようになってきている゙'が，不要な侵襲を椎体に加える こと, 移植骨が小さく固定に不安が残ること, 移植骨が 椎体に刺さり込んで kyphosis になりやすいことなど, 改良すべき点がある。また，without bone graft 法もす べての頸部椎間板障害例に適応となるものではないが, 適応条件を厳密にして行えば手術侵襲も少なく, 今後も 選択すべき一つの方法と思われる。

いずれにせよ前方除圧術においては，いかにして春髄 や神経根への損傷を与えることなく突出椎間板や骨棘を 完全に除去するか, さらに術後の嗄声や外側大腿皮神経 損傷をはじめとする種々の合併症を防ぐかが最も重要な
点である。一方後方除圧術においては，単純な椎弓切除 術は現在脊柱管拡大術に取ってかわられつつある。ただ し，脊柱管拡大術においてはさまざまな術式が考察され ており，いずれの術式が最もよいかは今後の検討課題で あろう。椎弓切除術と拡大術とを比較した場合，われわ れの手術成績でも拡大術の方が改善率は高い結果を得 た.この理由として術後の春柱配列の安定性や硬膜外の 線維性結合組織の発育阻止のほか, 過度の除圧による神 経根の tethering の増強が拡大術ではある程度おさえら れることなどが考えられる。

頸部椎間板障害の病態は決して画一的ではなく, 個々 の症例により異なるため, 選択すべき手術法も一つの方 法に固執すべきではなく, 術前の検索を十分に行い, 最 も適切な方法を採用することが大切と考えられる。 


\section{おわりに}

頸椎椎間板障害に対する外科的治療は比較的容易であ ると考えがちであるが，それ自体機能外科の要素が強い ため, その適応には十分な考慮をすべきであり，また手 術操作にも細心の注意とともにしっかりとしたテクニッ クを習得すべきである。

\section{文 献}

1) Cloward RB : The anterior approach for removal of ruptured cervical disks. J Neurosurg 15:602-614, 1958.

2) Hirabayashi K, Satomi K : Operative procedure and results of expansive open-door laminoplasty. Spine $13: 870-876,1988$

3) Isu T, Kamada K, Kobayashi N, Mabuchi S: The surgical technique of anterior cervical fusion using bone graft obtained from cervical vertebral bodies. $J$ Neurosurg $80: 16-19,1994$.

4）岩崎喜信, 井須豊彦，阿部 弘：頸部椎間板障害に対す る手術法の選択。Neurol. Med Chir (Tokvo) 26:857 $-862,1986$.
5）岩崎喜信, 井須豊彦, 秋野 実, 阿部 弘：多椎間の頸 部椎間板障害に対する Combined method. Spinal Surgery $3: 143-146,1989$.

6）岩崎喜信, 飛駢一利, 阿部 弘, 秋野 実: 頸部脊椎症 の)長期予後. Spinal Surgery 6:7-14, 1992.

7) Jeffreys $\mathrm{R}$ : The surgical treatment of cervical myelopathy due to spondylosis and disc degeneration. J Neurol Neurosurg Psychiatry 49:353-361, 1986.

8) Kadoya S, Nakamura T, Kwak R : A microsurgical anterior osteophytectomy for cervical spondylotic myelopathy. Spine 9:437-441, 1984.

9) Kimura I, Oh-hama M, Shingu H : Cervical myelopathy treated by canal expansive laminoplasty. J Bone Joint Surg 66A : 914-920, 1984.

10) Koyama T, Handa J : Cervical laminoplasty using apatite beads as implants: Experiences in 31 patients with compressive myelopathy due to developmental canal stenosis. Surg Neurol 24:663-667, 1985.

11) Rosenorn J, Hansen EB, Rosenorn MA : Anterior cervical discectomy with and without fusion. $J$ Neurosurg $59: 252-255,1983$.

12) Smith GW, Robinson RA : The treatment of certain cervical spine disorders by anterior removal of the intervertebral disc and interbody fusion. $J$ Bone Joint Surg 40:607-624, 1958.

頸椎椎間板障害の主に外科治療法につき検討を加え報告した．前方到達法において注意すべきこと としては, 術中の操作による脊髄ならびに神経根の損傷を起こさぬようにすることは当然であるが, その他反回神経や移植骨採取時の外側大腿皮神経の損傷の防止も大切である. このためには, 手術顕 微鏡下での操作と, 反回神経ならびに外側大腿皮神経の解剖学的走行を熟知しておく必要がある. 術 後の non union を防ぐためには, 十分なボリユーしの移植骨を插入することと, 術後1 力月の硬性 カラーによる強固な頸部の安静を保つ必要がある.

後方除圧術は椎弓切除術よりも脊柱管拡大術の方が有効であり, 手術成績においても拡大術の方が 良好な結果であつた。 